\title{
Rat-bite fever
}

INSERM

\section{Source}

INSERM. (1999). Orphanet: an online rare disease and orphan drug data base. Rat-bite fever. ORPHA:31205

Rat-bite fever (RBF) is a systemic bacterial zoonosis occurring in individuals that have been bitten or scratched by Streptobacillus moniliformis or Spirillum minus-infected rats and characterized by high fever, a rash on the extremities, and arthralgia. 